\title{
DOROTA PROBUCKA
}

Uniwersytet Pedagogiczny im. KEN

$w$ Krakowie

\section{O EDUKACJI W ZAKRESIE PRAW ZWIERZĄT. TEORIA TOMA REGANA}

\begin{abstract}
Probucka Dorota, O edukacji w zakresie praw zwierząt. Teoria Toma Regana [About Education on Animal Rights. Tom Regan's Theory]. Studia Edukacyjne nr 43, 2017, Poznań 2017, pp. 351364. Adam Mickiewicz University Press. ISSN 1233-6688. DOI: 10.14746/se.2017.43.21

The article concerns a new educational theory based on the idea of animal rights. It was presented and developed by the American ethicist Tom Regan, which drifted its axiological base and was the initiator of socio-educational movement called Animal Rights Movement, to which joined other ethicists, educators, layers, veterinarians, and even theologians. The article contains analysis of Tom Regan's views on the issue of moral status of non-human beings, and consists of two parts. The first part concerns the criticism of ethical theories based on the idea of direct and indirect moral duties to animals. In the second part are discussed the main concepts and principles of a new way of thinking such as: inherent value, a subject of a life criterion, the respect principle and its derivatives.
\end{abstract}

Key words: animal rights, environmental ethics, Tom Regan, moral duties

\section{Wprowadzenie}

Druga połowa XX wieku związana była z rozwojem etyki środowiskowej występującej przeciwko przedmiotowemu, instrumentalnemu traktowaniu świata przyrodniczego oraz tradycyjnemu rozumieniu moralności zawężającej sferę odpowiedzialności wyłącznie do relacji międzyludzkich. Etyka środowiskowa propagowała nowe myślenie poszerzające zakres moralnej wspólnoty o istoty nieprzynależne do gatunku Homo sapiens. Jej zwolennicy dążyli do uwrażliwienia ludzi na tę problematykę, zainicjowania zbiorowej debaty oraz wprowadzenia nowego modelu edukacji. Do jednej z radykalnych wersji etyki środowiskowej należy zaliczyć teorię praw zwie- 
rząt zaproponowaną $\mathrm{w}$ latach osiemdziesiątych XX wieku przez amerykańskiego etyka Toma Regana. Nie był on twórcą samego pomysłu przypisania zwierzętom podstawowych moralnych uprawnień, ale nadał tej idei systematyczną, spójną, rozbudowaną argumentacyjnie postać. Pomysł wszak narodził się wcześniej, ponieważ o prawach zwierząt pisali i postulowali ich wprowadzenie: rzymski prawnik Ulpian Domicjusz, pisarze i filozofowie: Thomas Tryon, Lewis Gompertz, Henry Salt, Edward Williams Nicholson, Brigit Brophy. Pomimo tego, wystąpienie Toma Regana należy uznać za szczególnie znaczące z dwóch powodów: po pierwsze - stworzył on aksjologiczne podstawy teorii praw zwierząt, po drugie - zainicjował społecznoedukacyjne działania pod nazwą: Ruch Praw Zwierząt (Animal Rights Movement), do którego przyłączyli się nie tylko inni etycy, ale również pedagodzy, prawnicy, teologowie, weterynarze ${ }^{1}$. Obecnie wiele osób, specjalistów z różnych dziedzin, propaguje ideę praw zwierząt, a sama teoria jest przedmiotem poważnej akademickiej dyskusji.

Przede wszystkim, koncepcja ta wykracza poza schemat łączenia praw (resp. moralnych uprawnień) wyłącznie $\mathrm{z}$ osobową strukturą człowieka i tym samym możemy mówić zarówno o human rights, jak i o non-human rights. Zdaniem rzeczników teorii praw zwierząt, prawa podstawowe wywiedzione są zarówno z ludzkiej natury, jak i natury gatunków pozaludzkich, ponieważ wartości uobecniają się nie tylko w świecie kreowanym przez Homo sapiens. Ich nośnikami mogą być również zwierzęta, pomimo nieposiadania przez nie świadomości aksjologicznej oraz rozbudowanej zdolności do racjonalnego myślenia. Tym samym, przedstawiciele gatunków pozaludzkich nie powinni być traktowani dowolnie i wykorzystywani do cudzych celów, które nie są związane z ich dobrem. Brak świadomości aksjologicznej oraz rozwiniętej racjonalności nie może stanowić wystarczającego argumentu na rzecz instrumentalnego wykorzystywania i zabijania kogokolwiek. W teorii praw zwierząt moralny status zwierząt (resp. ssaków) porównywany jest do statusu małych dzieci albo ludzi intelektualnie upośledzonych, chorych psychicznie, cierpiących na demencję starczą itp. Czyż istoty te mają świadomość jakichkolwiek praw i dysponują zdolnością do ich werbalizacji połączoną z wysokimi kwalifikacjami intelektualnymi? Nie, a pomimo to ich interesy są reprezentowane przez sądownie ustanowionych przedstawicieli. Dlaczego? - Ponieważ przyjęliśmy, że ludzi ci są dysponentami podstawowych uprawnień, spełniających funkcję analogiczną do tarczy chroniącej bezbronnych i bezsilnych (Henry Shue ${ }^{2}$ ), immunitetu gwarantu-

${ }^{1}$ L. Finsen, S. Finsen, The Animal Rights Movement in America, New York 1994, s. 23-72.

${ }^{2}$ H. Shue, Basic Rights, Princeton 1980. 
jącego nietykalność (Wesley N. Hohfeld ${ }^{3}$ ), karty atutowej, która przebija wzgląd na zbiorowe interesy (Richard Dworkin ${ }^{4}$ ), albo znaku zakazującego wjazdu w ramach przepisów ruchu drogowego (Robert Nozick ${ }^{5}$ ). A zatem ci, którzy mają podstawowe prawa uzyskują przywilej traktowania ich w szczególny, ochronny sposób. Podkreślmy, nowatorski charakter teorii praw zwierząt polega na przyjęciu tezy, że przywilej ten nie musi odnosić się wyłącznie do ludzi, ale również istot pozaludzkich, oczywiście nie $\mathrm{w}$ pełnym zakresie, ale w podstawowym, dotyczącym prawa (right) do życia, niebycia krzywdzonym i niebycia niewolonym. Prawne konsekwencje (law) uznania tej tezy oznaczałyby ustawowy zakaz hodowania i zabijania zwierząt zarówno na pokarm, jak i "dla sportu”, wykorzystywania ich w przemyśle kosmetycznym, futrzarskim, farmaceutycznym i rozrywkowym, przeprowadzania eksperymentów medycznych i edukacyjnych. Radykalizm teorii praw zwierząt polega na tym, że jej rzecznicy nigdy nie wyrażą zgody na eksploatację istot pozaludzkich, dążąc do jej całkowitego zakazu.

\section{Krytyka teorii etycznych opartych na idei pośrednich i bezpośrednich obowiązków moralnych wobec zwierząt}

Niektórzy etycy uważają, że nasze obowiązki wobec zwierząt są zapośredniczone w naszych moralnych obowiązkach wobec ludzi. Tym samym, to nie bezpośrednio dobro zwierzęcia, ale dobro człowieka powinno być celem naszych działań. Regan określa ten typ myślenia mianem „indirect duty views". Drugi typ obowiązków moralnych o charakterze bezpośrednim, obowiązków realizowanych ze względu na dobro samego zwierzęcia, zostaje przez niego nazwany "direct duty views". Filozof ten odrzuca obydwie koncepcje, ponieważ pierwsza explicite aprobuje instrumentalne traktowanie zwierząt łagodząc jedynie jego najbardziej okrutne przejawy, natomiast druga uzależnia realizację moralnych obowiązków, na przykład od utylitarystycznej kalkulacji albo od pielęgnowania pewnych szczególnych postaw, takich jak: współczucie, miłosierdzie, życzliwość. Jego zdaniem, żadna $\mathrm{z}$ tych teorii nie jest wystarczająca i nie gwarantuje zwierzętom pełnej ochrony. Oczywiście, istnieje jeszcze jedna grupa teorii o charakterze skraj-

${ }^{3}$ W.N. Hohfeld, Fundamental Legal Conception as Applied in Judicial Reasoning, New Haven 1919.

${ }^{4}$ R. Dworkin, Biorac prawa poważanie, przekł. T. Kowalski, Warszawa 1998.

${ }^{5}$ Por. R. Nozick, Anarchy, State and Utopia, New York 1974. 
nie zachowawczym, akceptujących zastaną rzeczywistość, a wraz z nią obecny przedmiotowy i niepoddawany moralnym ocenom sposób traktowania zwierząt przez człowieka. Tym samym, wystąpienie Regana oznacza odrzucenie wszystkich trzech dotychczasowych teoretycznych wzorców określających relację człowiek - zwierzę. W jego przekonaniu różnica między tymi teoriami moralnymi związana jest $\mathrm{z}$ odmienną odpowiedzią na następujące pytania: Czy należy postulować stawianie granic ludzkiej wolności wówczas, gdy dochodzi do interakcji ludzi ze zwierzętami? Do jakiego stopnia i na jakiej podstawie owa wolność powinna być ograniczana? ${ }^{6} \mathrm{Hi}-$ storia etyki to historia różnych, często radykalnie rozbieżnych odpowiedzi na te pytania.

Zwolennicy teorii zachowawczych sądzą, że ludzka wolność w tym przypadku nie powinna być niczym limitowana, ponieważ zwierzęta przez sam fakt, że są zwierzętami nie zasługują na jakieś szczególne traktowanie. Z kolei, rzecznicy pośrednich obowiązków postulują ograniczanie ludzkiej wolności, ale nie ze względu na powinności moralne wobec istot pozaludzkich. Ich zdaniem, okrucieństwo wobec zwierząt mogłoby się przenieść na relacje międzyludzkie. Człowiek będąc okrutnym wobec zwierząt, daje bowiem zły przykład innym, ucząc ich okrucieństwa w ogóle.

Odpowiedź głosicieli idei bezpośrednich obowiązków jest inna. Powinniśmy stawiać granice ludzkiej wolności, ponieważ zwierzęta same przez się, właśnie dlatego że są zwierzętami, wymagają poszanowania i roztaczania troski.

\section{Krytyka teorii pośrednich obowiązków moralnych wobec zwierząt}

Zdaniem Regana, cechą wspólną wszystkich teorii pośrednich obowiązków jest traktowanie zwierząt jako środka, poprzez który ludzie mogą realizować swoje bezpośrednie powinności wobec innych ludzi ${ }^{7}$. Zgodnie z tą ideą, mamy moralne obowiązki wobec pozostałych reprezentantów gatunku Homo sapiens, z których niektóre zapośredniczone są w relacji ze zwierzętami, ale nie mamy żadnych bezpośrednich obowiązków wobec samych zwierząt. Regan sądzi, że stanowisko to można wytłumaczyć odwołując się do następującej paraleli: Nie mamy obowiązków wobec dzieł sztuki, natomiast ich ochrona wynika z naszych obowiązków wobec ludzi, którym owe dzieła sztuki podobają się i służą. Podobnie nie mamy żadnych moralnych powinności wobec zagrożonych wyginięciem gatunków pozaludzkich, a ich

6 Por. T. Regan, Defending Animal Rights, Urbana - Chicago, 2001, s. 4.

7 T. Regan, The Case for Animal Rights, Philadelphia 1983, s. 150. 
ochrona podyktowana jest służbą na rzecz ludzkości czerpiącej z istnienia tych gatunków różnego typu korzyści.

W przekonaniu Regana, teorią zawierającą przejrzystą, spójną wykładnię idei pośrednich obowiązków wobec zwierząt jest etyka Kanta, zgodnie z którą kryterium moralnej podmiotowości spełniają wyłącznie istoty racjonalne ${ }^{8}$. Funkcjonują one jako cele same w sobie, niezależnie czy są użyteczne dla kogokolwiek. Stąd człowiek, będąc istotą racjonalną, nie może być traktowany wyłącznie jako środek, a zawsze jako cel. Kant wyraźnie odróżnia istoty zdolne do myślenia od istot owej cechy pozbawionych. Podobnie jak Arystoteles i św. Tomasz postrzega istoty niezdolne do myślenia jako te, które nie mogą być celami samymi w sobie. Tym samym zwierzęta, zaliczane do istot nierozumnych, mogą, a nawet muszą być traktowane wyłącznie jako środek do celu, a celem tym powinien być zawsze człowiek ${ }^{9}$. Zwróćmy również uwagę, że w teorii Kanta obchodzenie się ze zwierzętami w sposób zmniejszający ich użyteczność oznacza traktowanie tych istot niezgodnie $\mathrm{z}$ ich naturą.

Zdaniem Regana, z teorii Kanta wynika postulat używania zwierząt zgodnie z potrzebami ludzkimi, z jednym zastrzeżeniem związanym z unikaniem okrucieństwa wobec nich. Jeżeli zatem nie jesteśmy okrutni, to samo wykorzystywanie zwierząt nie jest moralnie złe. Należy również zaznaczyć, że zakaz bycia okrutnym powinien być respektowany nie ze względu na dobro zwierząt, ale z powodów wychowawczych: gdyż kto jest brutalny wobec zwierząt, staje się również bezwzględny wobec ludzi. A zatem, w celach edukacyjnych należy propagować wrażliwość na los istot pozaludzkich, ponieważ dzięki temu ludzie staną się wrażliwsi w ogóle i tym samym czuli na los swoich pobratymców.

W przekonaniu Regana, współczesnym przykładem propagowania idei pośrednich, moralnych obowiązków wobec zwierząt jest kontraktualizm jedna z najbardziej wpływowych teorii polityczno-etycznych. Zwolennicy tej koncepcji interpretują moralność jako wynik dobrowolnie zawartego między ludźmi kontraktu, opartego na powszechnej zgodzie na ograniczenie własnej wolności $\mathrm{w}$ imię spodziewanych jednostkowych korzyści. Dwa czynniki charakteryzują ową umowę: motywacyjny, jakim jest interes własny, oraz decyzyjny, czyli racjonalność jednostek. Regan analizuje dwie wersje tej teorii: pierwszą - reprezentowaną przez poglądy Tomasza Hobbesa i Jana Narvesona oraz drugą - w wydaniu Johna Rawlsa. Przypomnijmy, że różnica między nimi polega na tym, że w przypadku pierwszej z nich każdy

8 Tamże, s. 176.

${ }^{9}$ I. Kant, Uzasadnienie metafizyki moralności, przekł. M. Wartenberg, Warszawa 1971, s. 96. 
uczestnik społecznej debaty ma świadomość własnych interesów, potrzeb, pragnień, celów, natomiast $\mathrm{w}$ drugiej wersji moralność jest zbiorem reguł, na które przystają wszyscy uczestnicy kontraktu, uprzednio zapomniawszy o swoich jednostkowych preferencjach, majątkowym statusie, zawodzie itp.

Regan podkreśla, że w obu przypadkach zwierzęta nie mogą być uczestnikami kontraktu. Wszak według Narvesona, nie są w stanie werbalizować swoich celów i przeprowadzać negocjacji oraz nie mają możliwości zrozumienia tego, co można nazwać racjonalnym interesem własnym ${ }^{10}$. Ich ochrona powinna być uwzględniana o tyle, o ile ludzie (uczestnicy kontraktu) będą nią zainteresowani. Tym samym, ewentualnie mogą liczyć na opiekę tylko te zwierzęta, których ludzie darzą sympatią, zaliczając do swoich pupili. W przypadku innych zwierząt postulat ochrony ich życia i roztaczanie troski nie ma żadnych podstaw.

Również z teorii Rawlsa nie wynika postulat objęcia istot pozaludzkich respektem moralnym, ponieważ uczestnicy umowy zapominając o swoich preferencjach i interesach nie tracą jednak świadomości bycia człowiekiem i nie muszą sobie zadawać pytania: Co byłoby gdybym urodził się zwierzęciem? Jak wówczas chciałbym być traktowany? ${ }^{11}$ Zdaniem Regana, jeżeli uczestnicy kontraktu wiedzą, że urodzą się ludźmi, to nie mają żadnego interesu w przypisaniu moralnego statusu tym, którzy ludźmi nie są i nigdy nie będą.

\section{Krytyka teorii bezpośrednich obowiązków moralnych wobec zwierząt}

Teorie moralnych powinności wobec zwierząt o charakterze bezpośrednim oparte są na tezie, że respekt moralny należny jest co najmniej niektórym istotom pozaludzkim ze względu na nie same. Zwierzęta na podstawie cechy jaką jest zdolność do cierpienia mają wartość samą w sobie, a ich przydatność dla człowieka ma charakter drugorzędny. Regan uznaje utylitaryzm za reprezentatywny dla tego sposobu myślenia, koncentrując swoją uwagę na jego hedonistycznej wersji. Jego zdaniem, pozorna atrakcyjność tej teorii związana jest $\mathrm{z}$ postulatem uwzględniania przyjemności i bólu wszystkich, których dane działanie dotyczy ${ }^{12}$. Nie możemy zatem wybiórczo traktować tych stanów i preferować odczucia wyłącznie wybranych jednostek. Stąd, po pierwsze - przyjemność i ból zwierząt powinny być uwzględniane $\mathrm{w}$ utylitarystycznych kalkulacjach, po drugie - stany te powinny być liczone na równi ze stanami ludzkimi. A zatem, egalitaryzm wy-

\footnotetext{
10 T. Regan, Defending Animal Rights, s. 10.

11 Tamże, s. 12.

12 Tamże, s. 200.
} 
rażony Benthamowską formułą „każdy liczy się za jednego, nie mniej i nie więcej" jest istotną cechą utylitarystycznego myślenia. Wszystkie istoty sensytywne (sentient beings), niezależnie od gatunkowej przynależności, są członkami moralnej wspólnoty i należny jest im moralny szacunek w równym stopniu.

Regan sądzi, że powyższemu stanowisku, pomimo jego atrakcyjności, można postawić konkretne zarzuty. Główny z nich dotyczy trudności związanych z pogodzeniem idei sprawiedliwości z postulatem maksymalizacji użyteczności oraz oszacowywania konsekwencji działań. Jego zdaniem, reguła równego traktowania $\mathrm{w}$ praktyce okazuje się wtórna i podporządkowana konsekwencjalistycznemu myśleniu oraz zasadzie maksymalizacji pozytywnych wyników. Tym samym, idea równości powiązana z zasadą użyteczności przestaje oznaczać stosowanie tej samej miary wobec wszystkich istot zdolnych do cierpienia. W efekcie, życie zwierząt nie liczy się tak samo jak życie ludzi, czyli nie ma jednakowej wartości. Uczestnicy danej sytuacji muszą przystać na preferowanie ludzkich, jednostkowych interesów i poświęcanie jednych istot $\mathrm{w}$ imię korzyści innych albo $\mathrm{w}$ imię możliwego przyszłego dobra. Ponadto zdaniem Regana, wzgląd na przyszłe dobro może usprawiedliwiać i dopuszczać stosowanie dowolnych metod służących jego osiąganiu, nawet najbardziej niegodziwych i niesprawiedliwych ${ }^{13}$. Stąd, wiodący charakter zasady użyteczności oznacza w praktyce instrumentalne traktowanie zwierząt i w pewnych sytuacjach również ludzi oraz dopuszczalność ich zabijania w imię całościowej, globalnej przewagi przyjemności nad cierpieniem. Regan podkreśla szczególnie tę kwestię. Jego zdaniem, w utylitaryzmie dopuszczalna jest zarówno eksterminacja zwierząt jak i ludzi pod warunkiem, że jest ona dokonywana bezboleśnie ${ }^{14}$. Tym samym, aksjologiczny status istot ludzkich i pozaludzkich przypominałby naczynia (receptacles), które mogą być zapełnione pozytywną albo negatywną wartością (przyjemność lub cierpienie), gdzie samo istnienie człowieka albo zwierzęcia nie ma żadnej wartości wewnętrznej. Regan koncentruje swoją krytykę na stanowisku Petera Singera - współczesnego orędownika utylitarystycznego myślenia, w przekonaniu którego zwierzęta nie mając świadomości własnego istnienia, nie są zainteresowane biologicznym trwaniem. Tylko ludzie dzięki rozwiniętej samoświadomości są zainteresowani dalszą egzystencją

${ }^{13}$ Tamże, s. 16.

14 T. Regan, The Case for Animal Rights, s. 205. Dopuszczalność bezbolesnej eksterminacji nie dotyczyłaby wszystkich ludzi, ale pewnej ich grupy: np. starców, chorych umysłowo, kalekich noworodków, czyli tych wszystkich, których bezbolesna śmierć byłaby uzasadniona ze względu na maksymalizację społecznej użyteczności. 
i tym samym ich życie jest cenniejsze od tych istot, które niczego nie planują ${ }^{15}$. Dlatego, jeżeli wartość życia ludzkiego jest nieporównywalna z wartością życia zwierząt, to postulat bezpośrednich moralnych obowiązków wobec istot pozaludzkich, oparty na respekcie dla ich cierpienia, traci $\mathrm{w}$ praktyce na znaczeniu.

\section{Teoria praw zwierząt}

Polemika Regana z Kantem i utylitarystami polega nie tylko na odrzuceniu głównych postulatów obu stanowisk, ale również na przejęciu pewnych ich cech. Przypomnijmy, że Kant akceptował wyłącznie pośrednie obowiązki człowieka wobec zwierząt. Regan odrzuca to stanowisko, inspirując się jednocześnie innym wątkiem kantowskiej etyki dotyczącym niewiązania moralnej słuszności działań z konsekwencjami. Filozof koncentruje swoją uwage na drugim imperatywie kategorycznym Kanta, wyprowadzając z niego definicję moralnej słuszności. Tylko te działania są słuszne, które nie traktują innych jednostek wyłącznie jako środek, a zawsze jako cel. Stąd główny postulat jego etyki - zasada poszanowania (the respect principle) będzie brzmieć: „Powinniśmy traktować jednostki jako cele same w sobie, zawsze jako cele, nigdy jedynie jako środki"16. Jednakże, trudno uznać tę formułę za kantowską z ducha. Wszak Kant opierał swój drugi imperatyw kategoryczny na idei człowieczeństwa (die Menschheit) i jego poszanowania. Regan natomiast wprowadza pojęcie jednostki (resp. osobnika - an individual), której zakres znaczeniowy obejmuje zarówno istoty ludzkie, jak i pozaludzkie mające immanentną wartość. Tym samym, żadna istota obdarzona tzw. wrodzoną wartością (inherent value) nie może być redukowalna do wartości użytecznościowej, czyli środka do realizacji cudzych interesów. Moralnie złe jest zatem uzależnianie jej wartości od stopnia przydatności dla innych.

Natomiast inspiracje myślą utylitarystyczną, od Benthama po Singera, dotyczyć będą tezy o istnieniu bezpośrednich powinności (direct duties) nie tylko wobec ludzi, ale również zwierząt. Wszak jesteśmy zobligowani do pewnych zachowań wobec istot pozaludzkich ze względu na sam fakt ich istnienia. Swoją teorię Regan nazwie mianem the rights view, wyraźnie podkreślając, że stanowi ona połączenie pewnych cech utylitarystycznego my-

15 Por. D. Probucka, Filozoficzne podstawy idei praw zwierząt, Kraków 2013, s. 89-95.

16 "We are to treat individuals who exist as ends in themselves, always as ends, never merely as means"; T. Regan, Defending Animal Rights, s. 17. 
ślenia $\mathrm{z}$ deontologiczną myślą kantowską. Podstawowa teza jego etyki brzmi: poza ludźmi istnieją inne istoty żyjące, które posiadają podstawowe moralne uprawnienia. Nasze działania są moralnie niesłuszne wówczas, kiedy owe uprawnienia lekceważą. Zauważmy, że w tym przypadku moralna słuszność byłaby bardziej podstawowa i niezależna od preferowanej przez utylitarystów użyteczności, ponieważ posiadanie praw jest niezwiązane $\mathrm{z}$ konsekwencjami. Tym samym, racją na rzecz zaniechania i potępienia np. morderstwa jest to, że czyn ten gwałci moralne i ustawowe prawo jednostki do życia. Zło moralne nie jest $\mathrm{w}$ tym przypadku związane $\mathrm{z}$ ilością bólu, sadystycznej przyjemności, albo ze stopniem realizacji preferencji, ponieważ konsekwencje tego czynu o charakterze jednostkowym albo zbiorowym nie mają żadnego moralnego znaczenia. Podkreślmy, w teorii Regana wartość działań jest niezależna od ich konsekwencji.

\section{Kategoria wartości wrodzonej (inherent value)}

Teza o istnieniu wrodzonej wartości jest kluczowa dla całej etyki Toma Regana. Wszak to właśnie jednostki, które mają wrodzoną wartość nie powinny być traktowane instrumentalnie, czyli wyłącznie jako środek do osiągania cudzych celów. Jednostki te nie powinny być również traktowane jak „naczynia na wartości” (receptacles of values) w celu osiągnięcia możliwie najlepszych konsekwencji, ponieważ ich wartość nie zależy od stopnia przyjemnościowych doznań i satysfakcjonującego życia ${ }^{17}$. To właśnie wobec tych istot mamy bezpośrednie obowiązki moralne, ponieważ to właśnie one są dysponentami podstawowych uprawnień moralnych. Należy na to stwierdzenie zwrócić szczególną uwagę, ponieważ rozumowanie Regana opiera się właśnie na przesłance, że obecność wartości wrodzonej jest podstawą moralnych uprawnieńn ${ }^{18}$. Ponadto wszyscy, którzy posiadają tę wartość są równi, niezależnie od tego czy przynależą do kategorii moralnych podmiotów, czy przedmiotów moralnej troski, a zatem niezależnie od tego czy są ludźmi, czy zwierzętami ${ }^{19}$. Tym samym, wszystkie istoty obdarzone wartością wrodzoną posiadają ten sam status moralny w co najmniej podstawo-

17 Regan nie utożsamia wartości wrodzonej (inherent value) z wartością wewnętrzną (intrinsic value). Ta druga, jego zdaniem, przysługiwałaby pewnym stanom psychofizycznym, takim jak przyjemność albo satysfakcja, których zaistnienie nie powinno mieć wpływu na moralny status jednostki.

${ }^{18}$ Należy pamiętać o ewolucji poglądów Toma Regana w kwestii umocowania podstawowych uprawnień. Przedstawione powyżej stanowisko zostało wyłożone w książce The Case for Animal Rights. W późniejszych pracach filozof odchodzi od akcentowania idei wartości wrodzonej na rzecz kategorii interesów (inrterests).

${ }^{19}$ T. Regan, The Case for Animal Rights, s. 240. 
wym zakresie i zajmują w świecie unikalną pozycję. Stąd, krzywda uczyniona jakiejkolwiek jednostce obdarzonej immanentną wartością jest tożsama z krzywdą pozostałych i nie może być usprawiedliwiona czyjąkolwiek korzyścią.

Jeżeli postrzegamy wszelkie podmioty moralne jako posiadające identyczną wartość wrodzoną (...) i jeżeli część krzywd uczynionych moralnym podmiotom jest tego samego rodzaju co krzywdy uczynione przedmiotom moralnej troski (...) to wówczas arbitralny byłby osąd, że przedmioty moralnej troski wartości wrodzonej nie posiadają ${ }^{20}$.

Teza ta ma ścisły związek nie tylko z równościowym charakterem omawianej wartości, ale również z jej niestopniowalnym wymiarem. Tym samym, pewne jednostki ją posiadają albo nie, ale nie mogą jej posiadać w stopniu wyższym bądź niższym.

Czy bycie żywym jest wystarczającym warunkiem posiadania wrodzonej wartości? - Nie, jest jedynie warunkiem koniecznym. Zdaniem Regana, cecha ta, choć podstawowa, nie jest najważniejszym kryterium zrównującym ludzi i zwierzęta $w$ ich aksjologicznym statusie. To nie sam fakt życia, ale bycie tzw. podmiotem życia (a subject of a life) powinno być głównym wyznacznikiem posiadania wrodzonej wartości. Stąd kategoria „życiowej podmiotowości" stanie się drugą wiodącą ideą reganowskiej etyki. W przekonaniu filozofa, bycie podmiotem życia to:

dysponowanie pewnymi przekonaniami, pragnieniami, posiadanie pamięci i pewnych wyobrażeń na temat przeszłości i przyszłości, zdolność do zmysłowego postrzegania, czucia bólu i przyjemności, posiadanie preferencji i interesów, umiejętność inicjowania działań celem ich realizacji, poczucie psychofizycznej tożsamości w czasie oraz poczucie dobrostanu własnej egzystencji, który byłby logicznie niezależny od stopnia spełniania cudzych interesów ${ }^{21}$.

Powyższe cechy posiada zdecydowana większość reprezentantów gatunku Homo sapiens, ale również istoty pozaludzkie należące do ssaków i ptaków są w stanie sprostać zawartym w powyższym kryterium wymaganiom. Istoty te, podobnie jak ludzie, mają umiejętności poznawcze oparte na działaniach zmysłów, zdolność do refleksji, namysłu oraz możliwość angażowania własnej woli. Istoty te mają pewne przekonania i pragnienia, pamiętają i przewidują, planują i nakierowują swoje działania na określony cel. Posiadają zdolność do odczuwania fizycznej przyjemności i bólu. Odczuwają strach i zadowolenie, gniew i samotność, frustrację i satysfakcję. Zdaniem

20 Tamże, s. 239. Por. D. Probucka, Filozoficzne podstawy idei praw zwierząt, s. 130-135.

${ }^{21}$ T. Regan, The Case for Animal Rights, s. 243. 
Regana, te psychofizyczne stany są dowodem mentalnego życia charakterystycznego nie tylko dla ludzi, ale również dla co najmniej niektórych zwierząt22 - oto wspólna, poszukiwana przez Regana płaszczyzna. Egzystencja nie tylko ludzi, ale również istot pozaludzkich ma podmiotowy charakter. Kategoria życiowej podmiotowości będzie przez filozofa szczególnie podkreślana, albowiem jej wprowadzenie umożliwia wykroczenie poza tradycyjną dystynkcję oddzielającą podmioty moralne (moral agents) od przedmiotów moralnej troski (moral patiens) i niewiązanie praw (resp. moralnych uprawnień) z osobową strukturą ludzkiej egzystencji. Podstawowe prawa, takie jak prawo do życia, niebycia krzywdzonym, niebycia niewolonym nie muszą być zatem umocowane wyłącznie $\mathrm{w}$ takich atrybutach jak racjonalność i autonomia.

W przekonaniu Regana, błędność tradycyjnego rozumowania widoczna jest w przypadku refleksji nad moralnym statusem małych dzieci albo ludzi intelektualnie ułomnych. Wszak nie mają oni zdolności do racjonalnego myślenia i działania, czyli cech typowych dla moralnej sprawczości i bycia osobą. A zatem, zgodnie $\mathrm{z}$ tym rozumowaniem istoty te nie powinny być dysponentami podstawowych uprawnień i nie powinny być objęte ochroną, jaką te uprawnienia dają. Dodajmy, że oznaczałoby to jednocześnie zgodę na ich instrumentalne traktowanie, przyzwolenie na zabijanie i krzywdzenie $\mathrm{w}$ imię cudzych korzyści. $\mathrm{W}$ tej sytuacji wykroczenie poza kategorię moralnej podmiotowości okazuje się konieczne, celem wykazania, że mimo wszystko małe dzieci i intelektualnie ułomni mają pewne podstawowe uprawnienia. Regan podkreśla, że istoty te niezależnie od stopnia rozwoju racjonalnego myślenia i możliwości samostanowienia są świadome swego istnienia, reagują na ból i pozytywne bodźce, doznają strachu albo poczucia bezpieczeństwa. Nie każde z nich jest w stanie władać językiem werbalnym, ale mimo to potrafią komunikować swoje pragnienia i potrzeby, okazywać radość i smutek. Są zatem podmiotami życia i ich wartość jest niezależna od rozwoju personalizacji23.

Dlaczego zatem moralne uprawnienia nie powinny przysługiwać również zwierzętom (ssakom), jeżeli posiadają one wszystkie te cechy, którymi dysponują małe dzieci i intelektualnie ułomni? - pyta etyk. Rozumowanie Regana jest typowe dla tzw. argumentu z marginalnych przypadków (argument from marginal cases). Jeżeli uznamy za moralnie złe zabijanie i krzywdzenie dzieci albo umysłowo upośledzonych uważając, że istoty te posiadają moralne prawo do życia i niebycia krzywdzonym, to nie istnieją wystarcza-

22 T. Regan, Defending Animal Rights, s. 43.

${ }^{23}$ Tamże, s. 100. 
jące podstawy, abyśmy uznali za moralnie dopuszczalne zabijanie i krzywdzenie istot pozaludzkich dysponujących tymi samymi empirycznymi atrybutami co wyżej wymieniona grupa ${ }^{24}$. Wzgląd na przynależność gatunkową nie powinien być $w$ tym przypadku najważniejszy, ponieważ świadczyłby o stronniczości i braku obiektywizmu. Byłby przejawem szowinizmu gatunkowego (speciesism). Ponadto, zwierzęta, analogicznie do dzieci i umysłowo upośledzonych, nie muszą być świadome posiadania jakichkolwiek uprawnień, ponieważ nie trzeba wiedzieć, że dysponuje się pewnym uprawnieniem, żeby rzeczywiście je mieć. W ich imieniu przed sądem mogliby występować rzecznicy, których funkcja byłaby porównywalna do tych, którzy obecnie reprezentują interesy ludzi niezdolnych w sensie intelektualnym i fizycznym do osobistego stawiennictwa.

\section{Zasady moralnego postępowania}

W przekonaniu Regana, najważniejszą dyrektywą nowej etyki powinna być zasada poszanowania (the respect principle), zgodnie z którą powinniśmy okazywać szacunek wszystkim jednostkom obdarzonym wrodzoną wartością, spełniającym tym samym kryterium życiowej podmiotowości. Regan interpretuje tę dyrektywę jako jedną z wersji formalnej zasady sprawiedliwości domagającej się równości traktowania tych wszystkich, którzy należą do tej samej kategorii zasadniczej oraz oddawania każdemu tego, co się jemu należy. A zatem, to $\mathrm{w}$ imię moralnej sprawiedliwości powinniśmy okazywać równy szacunek tym wszystkim jednostkom, które mają wrodzoną wartość, czyli należą do tej samej kategorii zasadniczej, niezależnie czy są ludźmi czy zwierzętami. Ów szacunek jest właśnie tym, co im się należy i oznacza celowościowe, nieprzedmiotowe podejście. Natomiast, brak poszanowania polegałby na ich instrumentalnym traktowaniu, czyli sprowadzaniu do środka służącego realizacji cudzych celów ${ }^{25}$.

Z powyższej dyrektywy Regan wyprowadza drugą zasadę swojej etyki (the harm principle) i związany z nią postulat nieszkodzenia. A zatem, bez względu na okoliczności szkodzenie jednostkom należącym do kategorii podmiotów życia jest moralnie złe. Filozof chcąc ukazać możliwość wywiedzenia zasady nieszkodzenia $\mathrm{z}$ dyrektywy postulującej okazywanie szacun$\mathrm{ku}$, wskazuje na istotną cechę charakterystyczną dla życiowej podmiotowości, jaką jest możliwość doświadczania stanów pozytywnych i negatywnych.

${ }^{24}$ Tamże, s. 101. Rozumowanie to przyjmuje jeszcze jedną postać. Jeżeli argumentem na rzecz przedmiotowego traktowania zwierząt jest brak występowania u nich pewnej cechy, to zawsze można znaleźć marginalny przypadek człowieka, który tej cechy również nie posiada, a jest on pod ochroną moralnych, a nawet ustawowych uprawnień.

25 T. Regan, The Case for Animal Rights, s. 263. 
Stąd, pojęcia korzyści i szkody muszą się stosować do naszego myślenia o jednostkach obdarzonych wartością wrodzoną. Korzyści związane byłyby $\mathrm{z}$ realizacją celów leżących $\mathrm{w}$ interesie jednostki, natomiast do szkody prowadziłoby to wszystko, co owe korzyści ogranicza. Jeżeli wszystkie podmioty życia dążą do unikania szkody, to tym samym naszą moralną powinnością powinno być poszanowanie owej dążności ${ }^{26}$. W tym miejscu konieczna jest semantyczna analiza kategorii szkody (harm) oraz namysł nad jej adresatami. Regan podaje jej dwie definicje. W pierwszym przypadku szkodzenie oznacza powodowanie cierpienia fizycznego, natomiast $\mathrm{w}$ drugiej wersji to deprywacja, radykalne obniżenie jakości życia ${ }^{27}$. Kogo zatem dotyczyłby zakaz szkodzenia, czyli zadawania cierpienia i deprywowania? Tych wszystkich, którzy nie szkodzą innym oraz tych, którzy należą do kategorii niewinnych, obejmującej te istoty, które nie są zdolne do moralnej refleksji i ponoszenia odpowiedzialności za swoje czyny. Do kategorii tej filozof zalicza reprezentantów gatunku Homo sapiens nie spełniających wymogu moralnej sprawczości (human moral patiens) oraz zwierzęta (non-human moral patiens). Nie powinniśmy zatem szkodzić tym, którzy nie szkodzą innym oraz tym, którzy z racji swego ontycznego statusu są niewinni.

Kolejne zasady reganowskiej etyki związane są z odpowiedzią na pytanie o sposób postępowania w wyjątkowych sytuacjach, w których czynienie szkody staje się nieuniknione. Powinniśmy wówczas kierować się dodatkową dyrektywą, postulującą minimalizację liczby przekroczonych praw (the miniride principle) ${ }^{28}$. Zgodnie $\mathrm{z}$ nią, moralnie dopuszczalne jest lekceważenie prawa do poszanowania interesów wyłącznie u najmniejszej liczby jednostek uczestniczących w danej sytuacji. Wówczas, kiedy szkoda jest niemożliwa do uniknięcia, powinniśmy wybrać taką opcję, w której owej szkody będzie najmniej. Jeżeli zatem $\mathrm{w}$ przyszłości znajdziemy się w sytuacji konfliktowej, w której wszelkie możliwe rozwiązania będą łączyć się z nieuchronnym skrzywdzeniem, to powinniśmy wybrać taką opcję, która spowoduje krzywdę najmniejszej liczbie istot spełniających kryterium życiowej podmiotowości. Regan podkreśla, że reguła ta nie ma związku z utylitarystyczną kalkulacją i konsekwencjalistycznym myśleniem. Powinniśmy ją raczej interpretować jako pochodną naczelnej zasady poszanowania. A zatem, w sytuacjach skrajnych należy uczynić wszystko, aby respektować prawo do poszanowania u możliwie największej liczby istot podmiotów życia.

${ }^{26}$ Tamże, s. 262.

27 Tamże, s. 303.

${ }^{28}$ Tamże, s. 307. 
Jak zatem powinniśmy postępować w wypadku krzywd nieuniknionych o charakterze zróżnicowanym, wszak nie wszystkie szkody są sobie równe? W tej sytuacji zasada domagająca się okazywania szacunku możliwie największej liczbie istot niewinnych jest nieadekwatna. Regan proponuje zastosowanie innej reguły postulującej ochronę bardziej poszkodowanych (the worse-off principle ${ }^{29}$. Podkreślmy - $\mathrm{w}$ tym przypadku uwzględnianie liczby pokrzywdzonych nie powinno być wiodące. Należy bowiem bardziej chronić te istoty, których krzywda jest większa, nawet gdyby one były w mniejszości. Zgodnie z tą zasadą, możemy zlekceważyć prawo do poszanowania znacznej liczby pokrzywdzonych istot celem ratowania konkretnej jednostki doznającej największej krzywdy. Albowiem to wzgląd na wielkość jednostkowej szkody powinien być wyznacznikiem moralnej słuszności naszych działań.

\section{BIBLIOGRAFIA}

Dworkin R., Biorąc prawa poważnie, przekł. T. Kowalski, Warszawa 1998.

Finsen L., Finsen S., The Animal Rights Movement in America, New York 1994.

Hohfeld W. N., Fundamental Legal Conception as Applied in Judicial Reasoning, New Haven 1919.

Kant I., Uzasadnienie metafizyki moralności, przekł. M. Wartenberg, Warszawa 1971.

Nozick R., Anarchy, State and Utopia, New York 1974.

Probucka D., Filozoficzne podstawy idei praw zwierząt, Kraków 2013.

Regan T., The Case for Animal Rights, Philadelphia 1983.

Regan T., Defending Animal Rights, Urbana-Chicago 2001.

Regan T., Animal Rights, Human Wrong, New York 2003.

Regan T., Empty Cages. Facing the Challenges of Animal Rights, New York 2004.

Shue H, Basic Rights, Princeton 1980.

29 Tamże, s. 307. 